\title{
DEVELOPING THE WRITING PARAGRAPH THROUGH QUICKWRITING FOR JUNIOR HIGH SCHOOL AT SMP SWASTA PAHLAWAN NASIONAL
}

\author{
*Natasya Lia Aldilla Sitorus Pane \\ ** Prof. Dr. Hj. Sumarsih, M.Pd \\ **Tiarnita Maria Sarjani Br. Siregar S.Pd., M.Hum
}

\begin{abstract}
Pane, Natasya Lia Aldilla Sitorus. 2113321034. Developing the Writing Paragraph through Quickwriting for Junior High School at SMP Swasta Pahlawan Nasional. A Thesis. Engilsh and Literature Department, Faculty of Language and Arts. State University of Medan. 2018
\end{abstract}

This study deals with developing the writing paragraph through quickwriting for junior high school at smp swasta pahlawan nasional. The objectives of this study were to find out to improve the students' ability in writing paragraph of grade VIII students by using quickwriting strategy. Data data of the research was taken from the secondary grade of Junior High School Students at SMP Swasta Pahlawan Nasional Medan, which is taken from one class, contain 33 student. The data in this research collected by using interview and questionnaire. The interview and questionnaire will be given to collect the students' need, problem and interesting in learning English, particularly in writing and using quick writing in teaching and learning. In the teaching-learning process the teacher should prepare before conducting the lesson. The first is classroom procedures in teaching-learning process. Classroom procedures used by English teacher are opening, quickwriting, main activities (exploration-elaboration-confirmation), closing. There are some problems faced in the teaching-learning process. The problems faced are problem in developing idea, organizing idea, difficulties in vocabulary, tenses, and grammar, different capability of the students, and limited time. The consequently, the teacher should give solutions to cope the problems faced in teaching-learning process. So, the teacher should be creative to minimize the problem faced in teaching-learning process in order to make the students enjoy with the materials and develop student's ability.

Keywords : writing paragraph, quickwriting

*Graduate Status

**Lecturer Status 


\section{INTRODUCTION}

\section{Background of the Study}

Writing is as an important skill in the EFL setting. It helps learners to acquire English language because the activity stimulates thinking and facilitates them to develop some language skills simultaneously. According to Bello (1997), writing, as a productive language skill, plays an essential role in promoting language acquisition as learners experiment with words, sentences, and large chunks of writing to communicate their ideas effectively and to reinforce the grammar and vocabulary they learn in class. Barli (1995:7) states that writing is to produce or reproduce written a message. In this case, we get conclusion that writing is one of language skill use hand to transform what do we think in our brain in other words, writing is how do someone move what there are in their mind by written. Harris (1986: 68) statd that the writing process is a sophisticated skill combining five general components: contents, organization, grammar, vocabulary and mechanics.

The teaching of writing in our educational setting is slightly neglected for many years, since more communicative teaching methods emphasize speaking rather than writing. Besides, the writing culture in Indonesia is in fact still poor. Nowadays, the demand for writing in academic areas is increasing due to the impact of globalization. EFL students become more motivated to be able to write well in order to continue their education, participate in the academic world, and apply job.

Writing is not a skill that can be acquired by people naturally. Lenneberg (in Brown 2001: 334) states that human beings universally learn to walk and to talk, but that swimming or writing are culturally specific, learned behaviours. We learn to write if we are members of a literate society, and usually only if someone teach us. Besides, writing is also considered as a very complicated skill to learn. It involves a complex cognitive activity in which the writer should be able to organize some specialized skills at the same time, such as content, format, sentence structure, vocabulary, punctuation, spelling, and letter formation. Therefore, there 
is no doubt that EFL students find writing as a difficult skill to master because the process demands them to use many cognitive and linguistic strategies.

Not everyone can be an excellent writer, even in their own native language. Blanchard and Root (2003: 1) say that writing in a new language can be more difficult. Regarding the teaching writing in EFL setting, there are many differences between the first language writing and the target language writing, such as differences in using appropriate grammatical and rhetorical conventions and lexical variety. With so many issues around, the learning writing in English can be an intimidating task for EFL students. Consequently, the writing instruction in the classroom should provide students with a series of planned learning experiences to help them understand the nature of writing process.

In the second grade of Junior High School, the basic competency that should be achieved by students in the writing English subject is the ability to develop and produce written simple functional text in the descriptive text, recount text, and narrative text. However, the writing ability of grade VIII students still creates disappointment among students themselves as well as teachers. Students find difficulties in writing certain type of text, especially desciptive text. In writing descriptive text, the writer is required to have a good vocabulary mastery in order to be able to describe something/someone clearly. Students with poor vocabulary mastery often make mistake in selecting the appropriate words to describe the characteristics of the subject. Students also complain that they cannot think of anything significant enough to write. They spend much time at the planning stage yet they still confuse how to start their writing. They don't know how to organize their ideas and some of them don't even have any idea. With those problems, students find writing as a daunting task. It makes them less interested in writing. Moreover, the teacher uses writing materials and activities mostly from the textbook which is not effective to encourage and support students' learning.

Writing is how to produce a written product. It is a process of transforming ideas coherently and cohesively into written text. Written text is often resulted by a series of thinking activity but it requires skills that not naturally acquired. The good news is that writing involves skills that can be learned, practiced, and 
mastered. Teachers are demanded to plan appropriate classroom activities that support the learning of specific writing skills effectively at every stage - planning, drafting, revising, and editing. Seow (in Richards and Renandya 2002: 304) mentions that at the planning, teacher can help students generate ideas through such activities as brainstorming, clustering, and rapid free writing. Since writing is a thinking process, writers need to unlock the hidden ideas they have in minds in order to be able to start writing. According to Blanchard and Root (2003:41), quickwriting is a quick way to generate a lot of ideas on a subject. The purpose is to make a list of as many as ideas as possible without worrying about how will use them. It is very useful to help writers organize their thought, whether they have too many ideas or too few ideas.

Considering the issues above, the researcher is motivated to conduct classroom action research in which she used a brainstorming technique in the writing instructions. The study is an attempt to develop student's ability in writing paragraph through quickwriting of grade VIII students.

\section{REVIEW OF LITERATURE}

\section{Theory of Writing}

In the teaching and learning process, a language skill is divided into four language skills, namely: listening, reading, speaking, and writing. Listening and reading are categorized as receptive skills, while speaking and writing are categorized as productive skills. As productive skill, writing is considered more difficult by some students, both in the mother tongue and in a foreign language, than speaking.

Writing is to produce or reproduce written a message (Barli, 1995: 7). In this case, we get conclusion that writing is one of language skill use hand to transform what do we think in our brain in other words, writing is how do someone move what there are in their mind by written. The writing process is a 
sophisticated skill combining five general components: contents, organization, grammar, vocabulary and mechanics (Harris, 1986: 68).

Writing can be seen as mental process. First, the student will have to understand the function of language. He has learned for instance, that there are rule in language. These rules can be applied to express his idea. Words must be well selected. The corrrect rules are needed to make meaning comprehensible. In other words, there should be relations between one word to another or one sentence with other.

\section{Paragraph}

A paragraph is a group of sentences that fleshes out a single idea. In order for a paragraph to be effective, it must begin with a topic sentence, have sentences that support the main idea of that paragraph, and maintain a consistent flow.

Paragraph is a group of sentences that developed one main idea and develops a topic (Smalley, 1992: 3). Paragraph also stated as a set of sentences which explain a central idea (Palupi, 2010: 3). Paragraph is a part of written form which has a group of sentences that explain a certain central idea (Kosasih, 2003: 22). Based on the definition of paragraph that has been written before it can be concluded that Paragraph is a writing form which contain several paragraphs which develop one main idea.

\section{Quick Writing}

Quick writes are brief, timed writing opportunities that require only 3-10 minutes to integrate writing and critical thinking practice into any discipline. This article offers six ways you can use quick writes to help students become fluent, organized, confident, competent academic writers and thinkers.

First, determine how often to use quick writes. The more often use them, the more regular the practice and the faster the improvement in student writing. If possible, begin or end each class session with a quick write. It is unnecessary to collect every quick write or to grade quick writes at all. Spot checking is all that 
is needed. Begin with quick write sessions of three to five minutes followed by discussion, if time allows. Increase writing time as the term progresses or as the prompts become more complex.

Of course, not every student responds well to the idea of writing every day at least during the first few sessions. Some students claim they don't have anything to say, or they write a couple of sentences and then stare off into space. I tell students that if they get stuck, I will be happy to "unstick" them, and if I notice that someone is not writing, I go to them and offer help. In my experience, as students become habituated to writing, their skills improve and resistance evaporates.

\section{Teaching Writing Paragraph through Quick writing}

In teaching writing through quick writing is a series of cativity that stimulate students to write paragraph using quickwriting. The steps of teaching process are as follows.

a. Give time to students to think about a topic, they want to write, pick the issues which is had different perspective.

b. Request to each students to prepare the reason why choose the topic

c. Giving chance to students to write that require only 3-10 minutes to integrate writing about the topic.

This article offers six ways you can use quick writes to help students become fluent, organized, confident, competent academic writers and thinkers.

d. Students perform their writing in front of the class, and open discussion session.

e. Then, teacher conclude the material.

\section{RESEARCH METHODOLOGY}

This research was conducted based on educational research and development $(\mathrm{R} \& \mathrm{D})$. Educational research and development is a process used to 
develop validates educational products e.g textbook, instructional films, method of teaching or method for organizing instruction (Borg \& Gall, 2003).

In addition, Borg and Gall also recommend to simplify the stages of research for thesis and dissertation in a smaller scope. The simplefied stages are as follows:

1. Gathering information

2. Analyzing the data

3. Designing new reading material.

4. Validating new reading materials

5. Revising new reading materials as suggested by expert.

6. Revised-developing reading material (final product)

The data of the research was taken from the secondary grade of Junior High School Students at SMP Swasta Pahlawan Nasional Medan, which is taken from one class, contain 33 student. The subject of the research will be treated and observed in order to know their ability in writing paragraph especially through quick write.

The data in this research collected by usig interview and and questionaire. The interview and questionaire was given to collect the students' need, problem and interesting in learning english, particularly in writing and using quick writing in teaching and learning.

Quick writing as a technique of writing especially for writing. Crawford, Saul, Mathews and Makinster (2005:27) state that quick writes is a brief written reflection on a topic. It means that this strategy asks short feedback in written form of a topic which is stated by the teacher.

In collecting the data, the steps are as follows:

1. Gathering information from SMP Swasta Pahlawan Nasional about learning activity and environtment and data of students' need that was taken from questionaire and interview. 
2. Analyzing the students, need and existing material based on the data and information collected. Before starting the development of teaching media, teacher should begin with identifying the need

3. Designing teaching material based on the students' need.

4. Evaluating or validating new teaching media by expert. The experts are english teacher in SMP Swasta Pahlawan Nasional Medan. The evaluation or validation or validation process should be guided by advisor. The evaluation or validation focus on the media and material used.

5. Revising teaching media based on experts' suggestion.

6. Revised-developing teaching media (final product)

\section{RESEARCH FINDINGS AND DISCUSSIONS}

\section{Research findings}

The main points of this chapter is to describe the classroom procedures of teaching writing descriptive text, the teachers' techniques in teaching descriptive text, the problems faced in teaching writing descriptive text and the solutions applied by the teacher.

a. The classroom procedures of teaching writing descriptive text In general, the teacher used School-based Curriculum. The procedures are opening class, main activities, and closing class. There are three steps in the main activities: exploration, elaboration, and confirmation.

b. The techniques used to teaching writing descriptive text using quickwriting.

1) Describing the picture

English teacher always used picture to teach descriptive text. That strategy can improve students' creativity. The teacher used this technique at $\mathrm{A}$ and $\mathrm{B}$ class. Describing pictures is the effective technique. From the picture, the students could imagine about what they saw. The teacher also said to the students that with picture, they could describe about the picture. 
2) Feed back

The teacher applied feedback technique in teaching descriptive text. It was very effective technique, because it helped them to make a good and correct writing. They knew their errors, they knew the reasons why that were wrong, and then they could correct it by themselves.

3) Real object

The teacher used real object to teach English at B class.

4) Memorization

Based on interview with some students, this strategy was commonly used by English teacher. This strategy is the one of strategies to improve students' ability to memorize the new vocabulary.

5) Translating

Translating is when the teacher asked students to translate some sentences. Teacher helped the students when they find difficulties and confused in translating sentences.

6) Grouping

The teacher also used grouping strategies to manage the class activity. The teacher divided students in a group.

7) Correcting

Based on observation, the teacher always corrected the student's work and checked student's understanding of the new vocabularies or material that explained by teacher. While the students practiced the works, sometimes they made some mistakes, so the teacher used the strategy to correct their works.

\section{Discussion}

Problem faced in teaching writing using quickwriting are problem in developing the idea. They could not develop the paragraph well, they usually wrote in simple sentences. Students always asked teacher how to write something. The students admitted that this problem was due to the difficulties of transforming the ideas from their mind into written text. Problem in organizing the idea The second is problem organizing the idea. Students did not know the way to deliver 
organizing ideas to write descriptive text. In organizing ideas students have to use two components of generic structure of descriptive text, there are identification and description. Difficulties in vocabulary, tenses, and grammar Based on interview to English teacher, students have many difficulties about vocabulary and grammar. They have poor choice to choose the good vocabulary; it made the students always asked the teacher about the vocabulary that they did not know. They usually use the vocabulary that they known and if they have difficulty, they seldom look for the new vocabulary in dictionary, internet, or they want to ask the teacher. The students felt difficult to use correct tenses and arrange the good sentences to support the paragraph. Different capability of the students. Some of students could understand faster and the others learned slowly. That situation make the teaching learning process did not run well. Every student has different ability. Limited time Based on observation, one of the problems faced by teacher is limited time. The teacher felt difficult to deliver all materials to the students. The teacher has not enough time with $2 \times 40$ minutes in each meet. Whereas, the material about descriptive text just one meet. It made the teacher felt difficult to give the material. With the available time the English lesson could not run well.

Teacher's solutions of problems faced in teaching writing descriptive text. 1) Teach how to write descriptive text. The first solutions is explained the material clearly. Started by explained the pattern of simple present tense. After that give example of adjective that used to write descriptive text. The students had to improve their vocabulary.

Give simple assignment The teacher seldom gives students difficult assignment that made the students confused. The teacher just asked the students to do the simple assignment. That solution helped the students with low understanding the material. Repeat the previous material The teacher gave some practices to the students in the bottom level about understanding material. The students had to repeat the previous materials until the students understood the material.

Used mix languages The teacher always used two languages to teach English. Because not all of students knew the meaning of teacher's said if teacher 
used full English in the lesson. In the teaching activity, teacher did not use English language fully. She combined with Indonesian language, because the students still got difficulties to understand English language. So, in one utterance the teacher used 2 languages.

Based on the discussion of the findings, it can be concluded that quickwriting strategy is good to be a choice in teaching learning program, especially in writing paragraph. But, this strategy has its disadvantage, that made it cannot develop the process of teaching decriptive paragraph, because many students are having less capability in in understanding and using tenses, then students also have a limited vocabulary in use.

\section{CONCLUSIONS AND SUGGESTIONS}

\section{Conclusion}

In the teaching-learning process the teacher should prepare before conducting the lesson. The first is classroom procedures in teaching-learning process. Classroom procedures used by English teacher are opening, quickwriting, main activities (exploration-elaboration-confirmation), closing. Using some techniques in teaching writing is to help the teacher convey the materials when teaching-learning process. The teacher should use several techniques in teaching writing process. The consequently, the teacher should use effective technique based on classroom's condition to make the students more active in teaching writing especially writing descriptive text. So, the teacher should have update their knowledge about technique to use in the writing class in order to make the students more interesting to learn writing especially writing descriptive text. There are some problems faced in the teaching-learning process. The problems faced are problem in developing idea, organizing idea, difficulties in vocabulary, tenses, and grammar, different capability of the students, and limited time. The consequently, the teacher should give solutions to cope the problems faced in teaching-learning process. So, the teacher should be creative to minimize the problem faced in teaching-learning process in order to make the students enjoy with the materials and develop student's ability. 


\section{Suggestion}

The result of this research is expected to be beneficial for the English teacher in Vocational High Schools and other materials developers.

1. The first suggestion is related to the input of the materials. Based on the results of the needs analysis, it is suggested to provide texts that contain current relevant vocabulary. The texts can be adopted or adapted from many sources. It is also suggested to insert some pictures for the need of materials' presentation. The pictures may help the students to acquire the materials well and motivate students in the learning process.

2. The second suggestion is about the learning activity. The results of the needs analysis show that the activities that the students want are various. It is suggested to provide relevant activities for each skill. The activities for the spoken section (listening \& speaking) should be different from the activities for the written section (reading $\&$ writing). The spoken activities could be identifying detail information of a text or having a role-play, while answering comprehension questions based on the text given and completing blanks in incomplete texts could be put in the written section.

3. The third suggestion is concerned about the learners' role and teacher's role. The teaching and learning process can run well with the roles of both teacher and learner. From the results of the needs analysis, it is suggested to provide tasks which involve students to actively participate in the classroom discussion. The teacher also should be able to create an interesting environment of a teaching and learning process.

4. The last suggestion deals with the lay-out of the materials. The students' motivation of learning may come from interesting materials. The availability of the pictures is not only for aesthetic purpose, but it also helps the students to receive the input and produce an output well. The fonts and colors that are used should support the materials presentation.

\section{REFERENCES}

Adelstin, Michael E., and Joan G. Pival, The Writing Commitment, New York: Harcourt Brance Jovanovich, Inc, 1976. 
Aqib, Zainal, Penelitian Tindakan Kelas Untuk Guru SMP, SMA, SMK, Bandung: CV. Yrama Widya, 2008.

Axelrod, Rise B, and Charles R. Cooper, The ST. Martin's Guide to Writing, New York: ST. Martin“es Press, 1985.

Braine, George, and Julia M. Burks, Let's Write English, New York: Litton Education Publishing, 1980.

Braine, George, Witing from Sources, New York: Mayfield Publishing Company, 1996.

Bridges, Charles W, and Ronald F. Lunsford, Writing, Discovering Form and Meaning, California: Wadsworth Publishing Company, 1984.

Brittin, Norman A., A Writing Apprenticeship, New York: Holt, Rinehart, and Winston, Inc, 1968.

Buscemi, Santi V., A Reader for Developing Writers, New York: McGraw Hill Company, 2002.

Canavan, P. Joseph, Paragraph and The Short Theme, New York: Raytheon Education Company, 1969.

Celce-Murcia, Mariane, Teaching English as a Second Language or Foreign Language, Boston: Hainle \& Heinle, 1991.

Cowan, Elizabeth, Writing, Brief Edition, Texas: Scott, Foresman, and Company, 1993.

Fine, Barbara Clouse, The Student Writer, New York: McGraw Hill, 2002.

Fink, Lila, Phyllis Levy, Charlotte Miller, and Gwen Brewer., A Text for Writing and Reading. Boston: Little, Brown and Company, 1983.

Harmer, Jeremy., The Practice of English Language Teaching, London: Longman, 1991.

Huges, Arthur, Testing for Language Teachers, London: Cambridge University Press, Second edition 2003

Kistono, et. al., The Bridge English Competence for SMP Grade VII, Surabaya: Yudistira, 2006.

Langan, John, College Writing Skills with Reading, New York: McGraw Hill 
Companies, 2001.

Mattix Dietsch, Betty, Reasoning and Writing Well, New York: McGraw Hill, 2003.

McDonough, Jo, and Christopher Shaw., Materials and Methods in ELT, Cambridge: Blackwell Publisher, 1993

Miller, Robert Keith, Motives for Writing, New York: McGraw Hill, Inc, 2006.

Muslich, Mansur, KTSP (Kurikulum Tingkat Satuan Pendidikan)

Dasar Pemahaman dan Pengembangan, Jakarta: PT Bumi Aksara, 2007

Nunan, David, Language Teaching Methodology, New York: Phoenix ELT, 1995.

Richards, Jack C. and Theodore S. Rodgers., Approach and Methods in Teaching, London: Cambridge University Press, 1996.

Scholes, Robert, and Nancy R. Comley, The Practice of Writing, New York: ST. Martin's Press, 1985.

Tyner, Thomas E, Writing Voyage, California: Wadswoth Inc, 1985.

White, Ron, and Valerie Arndt, Process of Writing, London: Longman, 1998. Zinsser, William, On Writing Well, New York: McGraw Hill Company, 2002. 